\title{
The Impact of Using CALL Online Writing Activities on EFL University Students' Writing Achievement
}

\author{
Zuhair D. Zaghlool \\ Department of English Language and Literature, College of Languages and Translation, Al-Imam Muhammad Ibn Saud \\ Islamic University, Riyadh, Saudi Arabia
}

\begin{abstract}
This study aims to investigate empirically the effectiveness of using CALL online writing activities on EFL university students' writing achievement. It also attempts to reveal students' attitudes towards using CALL online writing activities in teaching writing. The sample of this study comprises forty randomly-selected male sophomore students. They are assigned to two groups: experimental and control. Both groups are taught via the regular writing teaching method; the experimental group received additional training using CALL online writing activities for eight weeks. An experimental pretest-posttest control group design is employed in this study. The instruments of the study are a writing achievement pre-posttest and a five-point Likert scale questionnaire. The results of the study revealed that there were no statistically significant differences between the achievement of the experimental group and the control group due to using CALL online writing activities. The results also indicated that EFL university students had positive attitudes towards using CALL online writing activities in teaching and learning writing. They believed that CALL online writing activities were useful, motivating, and enjoyable in addition to enhancing self-confidence and independent learning.
\end{abstract}

Index Terms-CALL, online, writing, experimental, control, attitudes, questionnaire

\section{INTRODUCTION}

The integration of computer-assisted language learning (CALL) into EFL classes has recently become an indispensable part of the teaching and learning process. This emphasis stems from the third phase of the history of CALL which is dominant nowadays. This phase is called integrative CALL which started the closing decade of the $20^{\text {th }}$ century due to the advent of the Internet, hypermedia, and email communication. Its ultimate aim is to integrate the four skills with each other and to integrate technology more fully into language teaching. It concentrates on real language use in a meaningful authentic context; it also encourages interactivity between the learner and Internet users around the world. Jafarian, Soori, \& Kafipour (2012) pointed out, "It seems that the role of computer in education and pedagogical practices will become more and more significant and inevitable in the twenty first century. English language pedagogy benefits from using computers at every level of instruction" (p. 139). Matsuda, Canagarajah, Harklau, Hyland, \& Warschauer (2003) added, "The diffusion of computers and the Internet is likely to be as important for the development of writing as was the earlier advent of the printing press" (p. 165).

In fact, the incorporation of CALL into educational settings has numerous merits. It provides learners with authentic material for study, enhances their independent learning, fosters their motivation, develops their higher order thinking skills since the information is presented in a nonlinear way, and breaks students' barriers towards learning. Pennington (2004) claims that teaching and learning in a writing class using CALL can promote more communicative dynamic learners' participation than in traditional classroom. Where students can communicate with each other over a network, the level of participation by individual students is increased, and additional opportunities for collaboration are made available. Networks also bring many different kinds of tools and sources of information within reach of student users. These potentials of CALL and computer networks both increase the learner's access to resources and add a new dimension to the $\mathrm{L} 2$ writing class.

It is worth illustrating that CALL applications and activities are used as a tool to supplement the process of teaching and learning, and the computer will never replace the teacher or the university professor. In addition, current CALL has changed the role of the teacher or the university professor from an imparter of information to a facilitator of learning, and the class has become more student-centered. Therefore, it is the teacher's or the university professor's responsibility in this integrative phase of CALL to search beforehand for relevant online applications and activities, so that students can access them easily without wasting their time. Levy (1997) defined CALL as the search for computer applications in language teaching and learning. Al-Nafisah (2015) adds that CALL presents, reinforces, and assesses interactive material for learning. CALL enables learners to access language teaching and learning applications. Additionally, Leffa, (2009) states that computer-assisted language learning as an approach to language teaching and learning can act as mediation and introduce a new paradigm in language teaching and research by emphasizing the relationship between the student and the instructor in the learning community. 


\section{Statement of The Problem}

Saudi university EFL students' writing performance is not satisfactory although written communication is of paramount importance for them as they need it in writing their projects, answering exams questions, taking notes, replying to emails, etc. Mastering the writing skill is a challenge for Saudi EFL students because it is a highly conscious productive activity which requires mental effort since the writer must juggle multiple issues simultaneously such as content, organization, purpose, audience, style, vocabulary, structure, punctuation, spelling, and capitalization. AlSalem (2010) found that Saudi EFL students' achievement in writing was lower than their achievement in other skills. He recommended that teachers should change the way they teach English language and try to use the technology in their teaching.

\section{SIGNIFICANCE OF THE STUDY}

The researcher hopes that this study will provide worthwhile feedback to EFL practitioners. University instructors or professors can integrate CALL online writing activities into their writing lectures, so their roles become facilitators of learning instead of providers of information. This study can help EFL students enhance their independent writing skill, confidence, and motivation. Moreover, this study is an addition to the body of researches carried out in Saudi Arabia in the realm of CALL, so it paves the way for more research to be carried out. Finally, administrators, textbooks evaluators, and curricula developers realize the crucial need to integrate technology into writing syllabuses. Therefore, this study attempted to investigate empirically the effectiveness of using CALL online writing activities on EFL university students' writing achievement. It also aimed to reveal students' attitudes towards using CALL online writing activities in teaching writing.

\section{PURPOSE OF THE STUDY}

This study attempts to investigate empirically the effectiveness of using CALL online writing activities on EFL university students' writing achievement. It also aims to reveal students' attitudes towards using CALL online writing activities in teaching writing.

\section{QUESTIONS OF THE STUDY}

The current study attempts to address two research questions:

1. Are there any statistically significant differences between the achievement of the experimental group and the control group on the pre-post writing test?

2. What are the experimental group students' attitudes towards using CALL online writing activities in teaching writing?

\section{LIMITATIONS OF THE STUDY}

This study is restricted only to paragraph writing. Besides, the findings are restricted to the number of the sample of the study which is forty EFL university students.

\section{LITERATURE REVIEW}

CALL has recently received gigantic interest from EFL researchers and practitioners. They point out that the integration of CALL in EFL language teaching can improve academic performance, enhance motivation, and promote learning (Alhaqbani, 2015; Alhujaylan, 2019; Al-Mansour \& Al-Shorman, 2009; Bataineh \& Baniabdelrahman, 2006; Cheng, 2005; Jenks \& Springer, 2002; Lin, 2002; Nuno, 2005; Sands, 2005; Verkler, 2004; Williams \& Williams, 2000). In addition, numerous experimental studies have been carried out on the effectiveness of using CALL on students' writing achievement. The samples of these studies were divided into two groups: control and experimental. Their results indicated that the achievement of experimental groups students who used CALL was significantly higher than their counterparts in the control groups (Al-Bataineh, 2010; Alhaqbani, 2015; Alhujaylan, 2019; Al-Jarf, 2004; AlMansour \& Al-Shorman, 2009; Almekhlafi, 2006; Al- Menei; 2008; Jafarian, Soori, \& Kafipour, 2012; Sahin \& Polatcan, 2019; Salameh, 2018; Shudooh,2003; Zaini \&Mazdayasna, 2014). However, few experimental empirical studies found that there were no statistically significant differences between in the writing performance of the experimental and control groups attributed to the use of CALL (Chen, 2005; Palenzuela, 2001).

The results of many experimental studies revealed that EFL students had positive attitudes towards using CALL in teaching and learning writing (Akbulut, 2008; Alhaqbani, 2015; Almekhlafi, 2006; Chiu, 2003; Hajimaghsoodi \& Maftoon, 2018; Lyons, 2002; Rahimi \& Hosseini, 2011). To conclude, the literature review emphasizes the integration of CALL into writing classes since it affects positively students' performance and attitudes. The current study is different from most of the studies reviewed because it tackled both the impact of using CALL on students' writing achievement and attitudes. 


\section{RESEARCH METHOD}

\section{A. Participants}

The sample of this study comprised forty male sophomore students enrolled in level three majoring in English language and literature at Al-Imam Muhammad Ibn Saud Islamic University in Riyadh during the academic year 20182019. The age of the participants ranged from nineteen to twenty years with an average of twenty. All of them were Saudi and they shared nearly the same socio-economic background. They were selected randomly from four writing sections. They were assigned randomly to two groups: experimental and control. Each group consisted of twenty students. The experimental group students were taught via the regular teaching method and CALL online writing activities for eight weeks. The control group students were not given special treatment and were taught via the regular teaching method.

\section{B. Design of the Study}

An experimental pre-test-post-test control group design was employed in this study because the participants were randomly allocated to the experimental and control groups; the two groups were tested before and after the experiment. The independent variable of the study was the method of instruction which was online CALL writing activities while the dependent variable was students' achievement on the writing test.

\section{Instruments of the Study}

The instruments of the study were a writing achievement pre-posttest and a five-point Likert scale questionnaire; these instruments were prepared by the researcher. The writing achievement pre-posttest was employed to answer the first question of the study. It consisted of three parts. Part one included a paragraph followed by six questions about paragraph organization. Part two was about rearranging scrambled sentences to form a coherent paragraph. Part three asked students to write a unified coherent paragraph of about ten lines about the following topic: "The house I wish to live in". The researcher prepared a detailed rating scale to correct students' answers. Moreover, the questionnaire was designed to answer the second question of the study which was about the experimental group students' attitudes towards using CALL online writing activities in teaching writing. It consisted of twelve close-ended statements; the levels of agreement of the questionnaire were as follows: Strongly Agree, Agree, Neutral, Disagree, and Strongly Disagree.

\section{CALL Online Writing Activities}

The Internet as a tool of CALL provides EFL learners with sheer engaging number of free interactive writing websites which contain numerous writing activities and exercises; they provide the learner with instant feedback. Therefore, the researcher accessed CALL websites and prepared the writing activities. These activities included the mechanics of writing, structure of the paragraph (topic sentence, supporting sentences, and concluding sentence), rearranging scrambled paragraphs, transition signals, organization of the paragraph (coherence, unity, and cohesion), types of paragraphs, and writing a paragraph then comparing it to an online one.

\section{E. Procedure}

The researcher reviewed the literature related to using CALL in teaching writing. He also accessed CALL interactive writing websites to prepare the instructional material for the experimental group. Then he prepared the instruments of the study which were a writing achievement pre-posttest and a five-point Likert scale questionnaire. The pre-posttest and the questionnaire were validated by a panel of five EFL university professors. These instruments were modified according to the panel's suggestions and comments. Furthermore, to ensure the reliability of the instruments, they were administered to a pilot sample of thirty randomly-selected EFL students from level three writing sections; this sample was excluded from the study. Then Cronbach Alpha formula was computed using SPSS program. The pre- posttest and the questionnaire were considered reliable since Cronbach Alpha was (0.84) for the pre- posttest and (0.81) for the questionnaire; these results were acceptable for the scientific research. After that, forty students were selected randomly from level three writing sections; they were divided randomly into two groups: experimental and control. Moreover, the researcher administered the writing achievement pre-posttest to both groups to ensure the homogeneity and equality of the experimental and control groups. The results were computed via the SPSS program utilizing the t-test for independent samples. The results are presented in Table 1.

TABLE 1

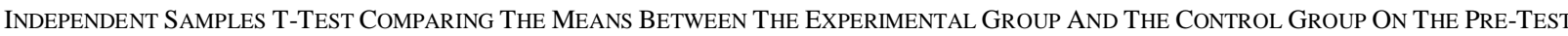

\begin{tabular}{lcccccl} 
Group & $\mathrm{N}$ & $\mathrm{M}$ & $\mathrm{SD}$ & $\mathrm{DF}$ & $\mathrm{T}$ & Sig. \\
\hline Experimental & 20 & 44.8 & 16.166 & 38 & 0.09 & $0.928^{*}$ \\
\hline Control & 20 & 44.3 & 18.733 & & & \\
\hline * Significant at & $\alpha \leq 0.05$ & & & & &
\end{tabular}

Table 1 indicates that there is a slight difference between the means of the experimental group and the control group since the mean of the experimental group is 
(44.8) and the mean of the control group is (44.3). In addition, it is evident from Table 1 that there is no statistically significant difference between the means of the two groups since the level of significance is $(0.928)$ which is more than (0.05). Therefore, this shows that the two groups were equal and homogenous before conducting the study.

Both groups received writing instruction via the regular method; the experimental group received two sessions of additional instruction in the computer lab via the CALL online writing activities for eight weeks; each session lasted for ninety minutes. Besides, email was utilized for communication and sending assignments between the experimental group students and the researcher. At the end of the experiment, the pre-posttest was administered to both groups, and the questionnaire was administered to the experimental group to measure their attitudes towards the experiment. A convenient way to evaluate CALL is through the investigation of students' opinions. Lasagabaster and Sierra (2003) believe that researchers should take into consideration students' opinions when CALL programs are evaluated because students are potential contributors in the development of language learning tools. Lynch (2000) recommends investigating all participants' opinions to evaluate CALL programs.

Finally, the collected data of the study were analyzed using inferential and descriptive statistics via the SPSS program. The results of the study were discussed, and conclusions were drawn from the results of the study.

\section{RESULTS}

To answer the first question of the study which is "Are there any statistically significant differences between the achievement of the experimental group and the control group on the pre-post writing test?" the pre-posttest was administered to the two groups. The independent samples t-test was carried out to figure out whether there were statistically significant differences between the achievement of the experimental group and the control group on the post writing achievement test. The results of the analysis of the post-test scores are shown in Table (2) below.

TABLE 2

INDEPENDENT SAMPLES T-TEST COMPARING THE MEANS BETWEEN THE EXPERIMENTAL GROUP AND THE CONTROL GROUP ON THE POST-TEST

\begin{tabular}{lcccccc} 
Group & $\mathrm{N}$ & $\mathrm{M}$ & $\mathrm{SD}$ & $\mathrm{DF}$ & $\mathrm{T}$ & Sig. \\
\hline Experimental & 20 & 69.6 & 14.520 & 38 & 0.09 & $0.066^{*}$ \\
\hline Control & 20 & 61.9 & 10.997 & & & \\
\hline * Significant at $\alpha \leq 0.05$ & & &
\end{tabular}

* Significant at $\alpha \leq 0.05$

Table (2) indicates that there is a difference between the mean scores of the experimental group (69.6) and the control group (61.9). Moreover, table (2) demonstrates that there are no statistically significant differences between the mean scores of the experimental and the control group since the level of significance is (0.066) which is higher than (0.05). Therefore, it can be concluded that there is no effect for using CALL online writing activities on EFL students' writing achievement.

To answer the second question of the study "What are the experimental group students' attitudes towards using CALL online writing activities in teaching writing?"

the five-point Likert scale writing questionnaire was administered to the experimental group students. The researcher calculated the total responses, means, and standard deviations for each statement of the questionnaire. Table (3) presents the total responses, means and standard deviations of the experimental group students' responses on each statement of the questionnaire. 
TABLE 3

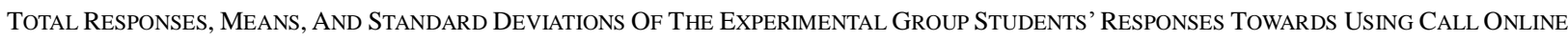
WRITING ACTIVITIES IN TEACHING WRITING

\begin{tabular}{|c|c|c|c|c|c|c|}
\hline No & Statement & $\mathrm{N}$ & Total & Mean & 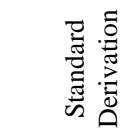 & 章 \\
\hline 1. & $\begin{array}{l}\text { CALL online writing activities are useful because they } \\
\text { improve my writing skill. }\end{array}$ & 20 & 92 & 4.60 & 0.503 & 1 \\
\hline 2. & $\begin{array}{l}\text { I like CALL online writing activities because I can access } \\
\text { them at anytime and anywhere. }\end{array}$ & 20 & 82 & 4.10 & 0.641 & 5 \\
\hline 3. & $\begin{array}{l}\text { CALL online writing activities are motivating and } \\
\text { enjoyable. }\end{array}$ & 20 & 91 & 4.55 & 0.510 & 2 \\
\hline 4. & $\begin{array}{l}\text { CALL online writing activities increase my writing self- } \\
\text { confidence. }\end{array}$ & 20 & 89 & 4.45 & 0.510 & 3 \\
\hline 5. & $\begin{array}{l}\text { CALL online writing activities should be integrated in any } \\
\text { writing course. }\end{array}$ & 20 & 70 & 3.50 & 0.889 & 6 \\
\hline 6. & $\begin{array}{l}\text { I feel comfortable when I access CALL online writing } \\
\text { activities. }\end{array}$ & 20 & 53 & 2.65 & 0.813 & 7 \\
\hline 7. & $\begin{array}{l}\text { CALL online writing activities enhance my independence } \\
\text { in learning the writing skill. }\end{array}$ & 20 & 87 & 4.35 & 0.587 & 4 \\
\hline 8. & $\begin{array}{l}\text { I think CALL online writing activities save time and } \\
\text { effort. }\end{array}$ & 20 & 44 & 2.20 & 0.1005 & 10 \\
\hline 9. & $\begin{array}{l}\text { I think CALL online writing activities promote student- } \\
\text { teacher interaction. }\end{array}$ & 20 & 34 & 1.70 & 0.733 & 12 \\
\hline 10. & $\begin{array}{l}\text { I like to access CALL online writing activities because I } \\
\text { can get an immediate feedback to my answers. }\end{array}$ & 20 & 52 & 2.60 & 1.095 & 8 \\
\hline 11. & $\begin{array}{l}\text { I think CALL online writing activities minimize my fear } \\
\text { of making mistakes. }\end{array}$ & 20 & 40 & 2.00 & 0.918 & 11 \\
\hline 12. & $\begin{array}{l}\text { CALL online writing activities provide me with authentic } \\
\text { writing materials. }\end{array}$ & 20 & 49 & 2.45 & 1.050 & 9 \\
\hline Total & & & 783 & 39.15 & 4.727 & \\
\hline
\end{tabular}

Table (3) indicates the EFL university students believe that CALL online writing activities are useful, motivating, and enjoyable. These results are drawn from statements number 1 and 3 "CALL Online writing activities are useful because they improve my writing skill; CALL online writing activities are motivating and enjoyable." which have got the first and the second ranks with the sums of (92 and 91) and the highest means (4.60 and 4.55). Another significant result is that CALL online writing activities enhance self-confidence and independent learning. These results are taken from statements 4 and 7 "CALL online writing activities increase my writing self-confidence; CALL Online writing activities enhance my independence in learning the writing skill." which are ranked the third and the fourth with very high means (4.45 and 4.35) and sums of 89 and 87. Moreover, students like CALL online writing activities because they have freedom to access them freely regardless of time and place. This result is manifested in statement number two which has scored a high mean (4.10) with the fifth rank. Students also support the integration of CALL online writing activities in any writing course. This finding is conveyed in sentence number five which is ranked the sixth and has scored a high mean (3.50). Finally, EFL university students don't agree that CALL online writing activities promote student-teacher interaction. This result is drawn from statement number 9 which has the lowest mean (1.70) and is ranked the twelfth. The following diagram illustrates the means of the statements of the questionnaire. 


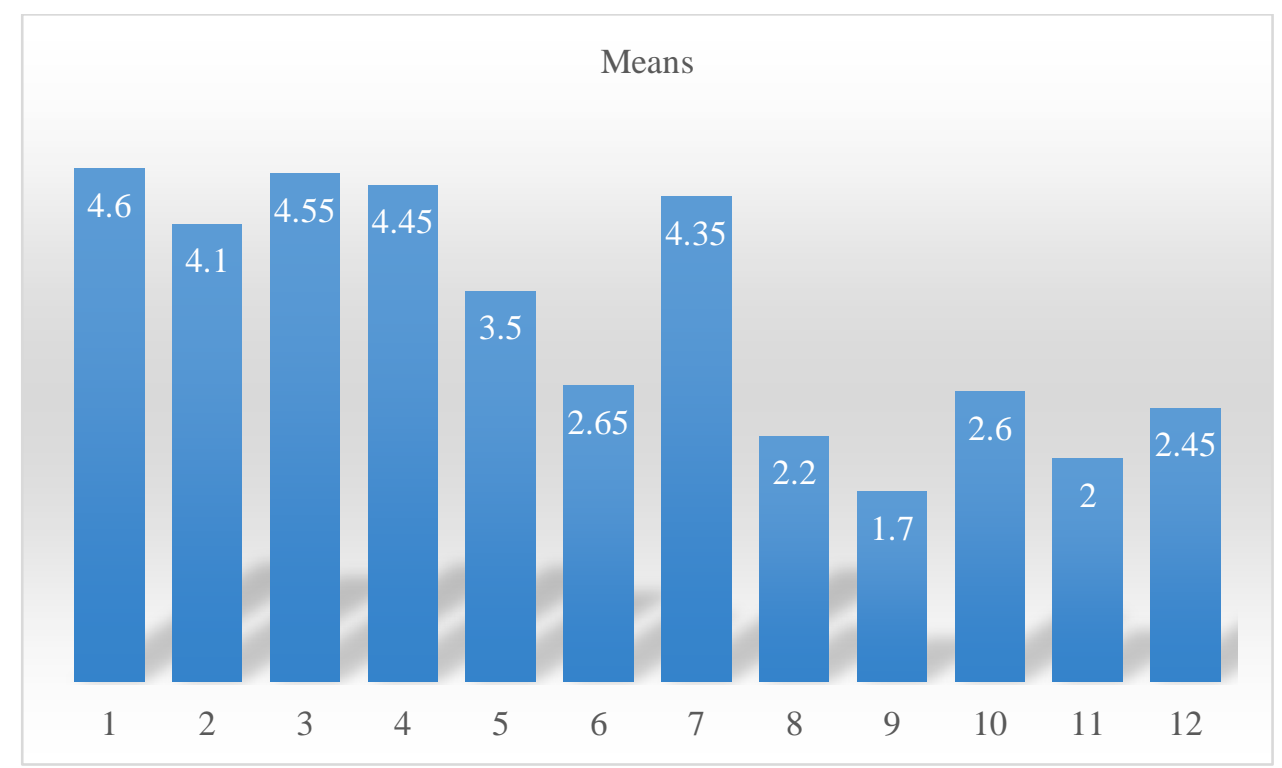

In order to identify students' attitudes towards the use of CALL online writing activities, the researcher calculated the total of each student's responses and analyzed them statistically to find out the mean and standard deviation of the experimental group. This is illustrated in Table (4).

TABLE 4

MEANS AND STANDARd DEVIATIONS Of THE EXPERIMENTAL GROUP TOWARDS USING CALL ONLINE WRITING ACTIVITIES IN LEARNING WRITING

\begin{tabular}{cccc} 
Group & $\mathrm{N}$ & $\mathrm{M}$ & $\mathrm{SD}$ \\
\hline Experimental & 20 & 39.15 & 4.727 \\
\hline
\end{tabular}

Table (4) indicates that the mean of the students' attitude towards using CALL online writing activities is 39.15 out of 60 and the standard deviation is 4.727. Since the mean of students' responses is higher than the mean of the questionnaire which equals $(3 \times 12=36)$, this shows that students have positive attitudes towards using CALL online writing activities in learning writing. Furthermore, to find out whether the difference between the mean of students' attitudes and the mean of the questionnaire is statistically significant, the researcher calculated the t-test for one sample. The results are presented in Table (5).

TABLE 5

One SAmple T-Test For The Difference Between The Mean Of Students’ Attitudes And The Mean Of The Questionnaire

\begin{tabular}{lllllll} 
Group & $\mathrm{N}$ & $\mathrm{M}$ & $\mathrm{SD}$ & $\mathrm{DF}$ & $\mathrm{T}$ & Sig. \\
\hline Experimental & 20 & 39.15 & 4.727 & 19 & 24.45 & $0.008^{*}$ \\
\hline
\end{tabular}

* Significant at $\alpha \leq 0.05$

Table (5) indicates that there are twenty students in the experimental group with the mean of 39.15 . It is also clear that there is a statistically significant difference between the means of the experimental group students' attitudes toward the use of CALL online writing activities and the questionnaire since the level of significance is 0.008 which is lower than (0.05). This proves that students have positive attitudes towards using CALL online writing activities in learning writing.

\section{Discussion}

The first finding of the study was that there were no statistically significant differences between the achievement of the experimental group and the control group due to using CALL online writing activities. This finding is in harmony with the two studies: Chen (2005) and Palenzuela (2001). It was not in line with many studies: Al-Bataineh (2010), Alhaqbani (2015), Alhujaylan (2019), Al-Jarf (2004), Al- Mansour \& Al-Shorman (2009), Almekhlafi (2006), AlMenei (2008), Hajimaghsoodi \& Maftoon (2018), Jafarian, Soori \& Kafipour (2012), Sahin \& Polatcan (2019), Salameh (2018), Zaini \& Mazdayasna (2014). This finding does not mean that using CALL online writing activities in teaching writing is ineffective. It might be a result of the regular method of writing instruction at the College of Languages and Translation at Al-Imam University which integrates CALL resources into writing instruction since classrooms are equipped with CALL resources such as the data show, the podium, and Internet access; moreover, 
writing textbooks also include writing Internet activities which enable students to get practice outside the classroom. This argument is backed by the questionnaire results which revealed that EFL university students had positive attitudes towards using CALL online writing activities in learning writing. They also believed that CALL online writing activities were useful, motivating, and enjoyable in addition to enhancing self-confidence and independent learning. These results are congruent with the findings of Akbulut (2008), Alhaqbani (2015), Al-Jarf (2004), Al- Mansour \& AlShorman (2009), Almekhlafi (2006), Chiu (2003), Hajimaghsoodi \& Maftoon (2018), Lyons (2002), Rahimi \& Hosseini (2011), Shudooh (2003). Finally, these results indicated that using CALL online writing activities were fruitful in teaching and learning writing. Therefore, university professors should permanently integrate CALL online writing activities into their writing classes; students should be encouraged to access these activities inside and outside the classroom.

\section{CONCLUSION AND ReCOMmEndations}

Although results of this study revealed that there were no statically significant differences between the achievement of the experimental group and the control group attributed to using CALL online writing activities, students had positive attitudes towards incorporating CALL in writing classes. Besides, EFL students indicated that CALL online writing activities were useful, motivating, and enjoyable; they enhanced self-confidence and independent learning. Therefore, it is recommended that CALL online writing activities should be integrated into every writing course. It is also recommended to replicate this study on essay writing with a larger sample, longer time span, and the addition of another instrument which is semi-structured interviews.

\section{REFERENCES}

[1] Akbulut, Y. (2008). Exploration of the attitudes of freshman foreign language students toward using computers at a Turkish State University'. The Turkish Online Journal of Educational Technology, 7 (1), 18 -31.

[2] Al-Bataineh, A. (2010). The effect of the Internet on improving foreign language students' writing performance. An-Najah Univ. J. of Res. (Humanities), 24(4), 1241-1258.

[3] Alhaqbani, M.H. (2015). Using MALL in the Saudi context: The case of WhatsApp in consolidating the writing skill of EFL preparatory year students at Al-Imam University. M.A. Thesis, Al-Imam Muhammad Ibn Saud Islamic University.

[4] Alhujaylan.H. (2019). An Assessment of the Effectiveness of CALL in Teaching English Language Writing Skills in Saudi Arabia. Arab World English Journal (AWEJ), 5, 5-27.

[5] Al-Jarf, R. S. (2004). The effects of web-based learning on struggling EFL college writers. Foreign Language Annals, 37, (1), 46-56.

[6] Al-Mansour, S. N. \& Al-Shorman, R.A. (2009). The effect of computer-assisted instruction on Saudi university students' learning of English. Journal of King Saud University- languages and Translation, 24(1), 51-56.

[7] Almekhlafi, A. (2006). The effect of computer assisted language learning (CALL) on United Arab Emirates English as a Foreign Language (EFL) school students' achievement and attitude. Journal of Interactive Learning Research, 17(2), $121-142$.

[8] Al-Menei, A. (2008). An investigation of the effect of computer-assisted writing instruction on EFL Saudi learners' ability. M.A. Thesis, King Saud University.

[9] Al-Nafisah, k. I. (2015). Designing a computer-assisted language learning (CALL) program and measuring its effect on Saudi EFL learner's achievement in English. International Conference on eBusiness, eCommerce, eManagement, eLearning and $\begin{array}{llllll}\text { eGovernance, } & \text { 78-87. } & \text { October } & 19, & 2019\end{array}$ https://pdfs.semanticscholar.org/e675/316389988f13e90cc92d3dee6595ca028769.pdf.

[10] Al-Salem, M. (2010). The Effectiveness of Cooperative-Online Synchronous Learning in Promoting Reading Skills of Freshman Female Students at the College of Languages and Translation. M.A. Thesis, King Saud University.

[11] Batainah, R. \& Baniabdelrahman, A. (2006). 'Jordanian EFL Students' Perception of Their Computer Literacy'. International Journal of Education and Development Using Information and Communication Technology, 2, (2), 35 -50.

[12] Chen, L. (2005). Examining the role of the computer in EFL instruction. Electronic Journal for the Integration of Technology in Education, 4, 30-63.

[13] Chiu, M. (2003). Computer Assisted Language Learning: Attitudes of Taiwanese College Students. Ph.D. Dissertation, The University of West Florida.

[14] Hajimaghsoodi, A. \& Maftoon. B. (2018). Iranian EFL learners' perception of the efficacy and affordance of activity theorybased computer assisted language learning in writing achievement. Journal of Teaching Language Skills (JTLS), 36 (4), 33-66.

[15] Jafarian, k., Soori, A., \& Kafipour, R. (2012). The effect of computer assisted language learning (CALL) on EFL high school students' writing achievement. European Journal of Social Sciences, 27 (2), 138-148.

[16] Jenks, M. \& Springer, J. (2002) A View of the Research on the Efficacy of CAI. Electronic Journal for the Integration of Technology in Education, 1(2), 43-58.

[17] Lasagabaster, D. \& Sierra, J. (2003). Students' Evaluation of CALL Software Programs. Educational Media International, 40 (3), 293-304.

[18] Leffa, V. J. (2009). CALL as action. In R. C. V. Marriott \& P. L.Torres (Eds.), Handbook of research on e-learning methodologies for language acquisition (39-52). New York: Information Science Reference. doi:10.4018/978-1-59904-994-6.

[19] Levy, M. (1997). CALL: Context and Conceptualisation. Oxford: Oxford University Press.

[20] Lin, N. T. (2002). Motivation and Attitude toward Integrated Instruction Through Technology in College-Level EFL Reading and Writing in Taiwan. Ph.D. Dissertation, University of Pittsburgh.

[21] Lynch, B. (2000). Evaluating a Project-Oriented CALL Innovation. Computer Assisted Language Learning, 13 (4), $417-440$. 
[22] Lyons, H. L. (2002). The effect of technology use on student writing proficiency and student attitudes toward written assignments in a ninth-grade Language arts classroom. Ph.D. Dissertation, Idaho State University.

[23] Matsuda, P. K., Canagarajah, A. S., Harklau, L., Hyland, K., \& Warschauer, M. (2003). Changing currents in second language writing research: A Colloquium. Journal of Second Language Writing, 12, 151-179. doi:10.1016/S1060-3743(03)00016-X.

[24] Nuno, J. A. (2005). Is Computer-Assissted Instruction an Effective Tool in the Reading-Writing Classroom? Ph.D. Dissertation, California State University.

[25] Palenzuela, E. (2001). Effects of computer-assisted writing instruction on fourth grade students. Ph.D. Dissertation, The Union Institute.

[26] Pennington, M. C. (2004). Electronic media in second language writing: An overview of tools and research findings. In S. Fotos and C. Browne (Eds.). New Perspectives on CALL for Second Language Classrooms (69- 92). Mahwah, NJ: Lawrence Erlbaum Associates.

[27] Rahimi, M. \& Hosseini, F. (2011). The impact of computer-based activities on Iranian high-school students' attitudes towards computer-assisted language learning. Procedia Computer Science, 3, 183-190.

[28] Sahin, A. \& Polatcan, N. (2019). The effect of creative writing exercises in Turkish classes on students' academic achievement: A meta-analysis. International Online Journal of Educational Sciences, 11 (2), 254-268.

[29] Salameh, L.A. (2018). Measuring the effects of web-based pre-writing activities on EFL learners' writing performance. British Journal of English Linguistics, 6 (2), 72-85.

[30] Shudooh, Y. M. (2003). The application of computers in writing classes. Ph.D. Dissertation, University of Cincinnati.

[31] Verkler, K. W. (2004). Technology in the Foreign Language Classroom. Journal of Educational Media and Library Science, 41 (4) $455-478$.

[32] Williams, H. S. \& Williams, P. N. (2000). Integrating reading and computer: An approach to improve ESL student reading skills'. Reading Improvement, 37 (3), 98-101.

[33] Zaini, A. \& Mazdayasna, G. (2014). The effect of computer assisted language learning on the development of EFL learners' writing skills. Procedia - Social and Behavioral Sciences, 98, 1975 - 1982.

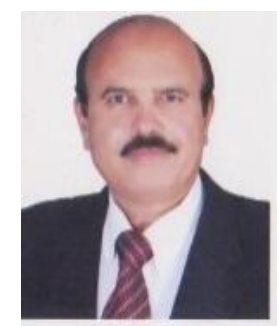

Zuhair Dawood Zaghlool is an assistant professor at the Department of English Language and Literature, College of Languages and Translation - Al-Imam Muhammad Ibn Saud Islamic University in Riyadh, Saudi Arabia. He got his Ph.D. from Amman Arab University for Higher Studies in English Language Curricula and Instruction. His research interests are in language acquisition and teaching English as a foreign language. 